\title{
Die eenheid van die Filippensebrief: Oorwegings vanuit die
} gedagtestruktuur van die brief

\author{
G J C Jordaan \\ Skool vir Bybelwetenskappe en Bybeltale, Fakulteit Teologie \\ Noordwes Universiteit, Potchefstroom
}

\begin{abstract}
The unity of the Philippian letter: Considerations from the thought structure of the letter

During the last two decades a new interest has emerged in the structure of the letter to the Philippians, leading to a variety of text oriented studies, which have more or less confirmed the unity of the letter. This article contributes to these studies by making a thoughtstructure analysis of the text of Philippians. This analysis, which takes the grammatical relations within the text as point of departure, but proceeds to a study of the more implicit markers of structure, such as repetition and figures of speech, reveals that the thoughts in the letter body of Philippians are arranged in a triangle pattern. In this pattern Philippians 1:27-30 serves as a "table of contents", which is expanded upon in the rest of the letter body (2:1-3:21). In a subtle way the main elements of the "table of contents" are echoed in Philippians 4:1-9, resulting in an "inclusio"-pattern. These patterns of thought structure of Philippians provide further support for theories in favour of the unity of the letter.
\end{abstract}

\section{INLEIDING}

Die kommentaar van Wolfgang Schenk (Die Philipperbriefe des Paulus, 1984) het nuwe vuur in die debat oor die eenheid van die Filippensebrief geblaas. In die kommentaar verdedig Schenk die teorie van 'n saamgestelde brief. Op sigself is dit niks nuuts nie. Die kompilasie-teorie gaan immers terug tot die begin van die negentiende eeu (vgl Koperski 1993:602). Wat Schenk se kommentaar egter merkwaardig maak, is dat hy die teorie verdedig aan die hand van 'n struktuur-ontleding van die teks, oftewel 'n "tekslinguistiese metode" soos hy dit noem (Schenk 1984:13). So 'n metode sou immers eerder by die verdediging van die eenheid van die brief pas (Combrink 


\section{Die eenheid van die Filippensebrief}

1989:142). Nietemin het Schenk met sy strukturele benadering aangetoon dat 'n teksgeoriënteerde, strukturele benadering 'n belangrike plek in die hedendaagse debat oor die eenheid van die Filippensebrief het. ${ }^{1}$ Hierdie artikel is dan bedoel om 'n verdere bydrae vanuit 'n strukturele benadering tot hierdie debat te lewer.

Benewens die studie van Schenk, is die struktuur van Filippense die afgelope twee dekades volgens verskillende teksgeoriënteerde metodes bestudeer, telkens ter bevestiging van die eenheid van die brief. 'n Epistolografiese ontleding het byvoorbeeld gekom van Ronald Russell (1982) en 'n meer literêre analise deur Robert Swift (1982); Duane Watson (1988) het 'n retoriese analise aangedurf en Peter Wick (soos bespreek deur Pretorius 1998:552-569) 'n struktuuranalise binne 'n retoriese raamwerk; van Luter \& Lee (1995) het 'n ontleding gekom wat hulle as "tematies" beskrywe ( Luter \& Lee 1995:91) en dan was daar ook die diskoersanalise deur David Black (1995). ${ }^{2}$ Luter \& Lee (1995:91) betreur die feit dat, hoewel elkeen van die studies ' $n$ inherente strukturele eenheid in die Filippensebrief blootlê, daar nie konsensus oor die struktuur-aangeleentheid bestaan nie. Pretorius (1995:291) wys egter daarop dat daar, vanweë die onlangse paradigmaskuiwe in die teologiese wetenskap, wel ruimte is vir die naasbestaan en samewerking van verskillende en selfs opponerende metodes.

\section{2. 'N ONTLEDING VAN DIE GEDAGTESTRUKTUUR}

Die doel van hierdie artikel is om die teks van die Filippensebrief vanuit 'n besondere struktuuranalitiese hoek te bekyk, naamlik dié van gedagtestruktuurontleding. Die bydrae van hierdie artikel is allermins 'n poging om die laaste woord te probeer spreek, ook nie om met 'n nuwe herrangskikking van die teks net nog 'n draai aan die "Rubik-blok" van die Filippense-studie (vgl Swift 1984:234) te gee nie. Dit is bloot bedoel as 'n verdere bydrae om vanuit die studie van die briefstruktuur die samehangende eenheid van die briefgeheel te bevestig.

Gedagtestruktuurontleding (GSO) as metode van teksanalise is volledig uiteengesit deur Christi Coetzee (1988:19-37). GSO is in werklikheid

\footnotetext{
${ }^{1}$ Pretorius (1995:277) wys daarop dat die meer teksgeoriënteerde, strukturele benadering besig is om toe te neem (vgl ook Roberts 1984:155; Pretorius 1998:552).

${ }^{2}$ Vir meer volledige besprekings van die afgelope twee dekades se ontledings van die Filippensebrief, vgl oorsig van Pretorius in Neotestamentica van 1995 en 1998.
} 
nie ' $n$ ander metode nie. Dit is verwant aan die meeste bekende metodes van struktuuranalise, maar het 'n besondere fokus deurdat dit vanuit die formele struktuur van 'n teks die gedagtegang van die skrywer wil beskrywe (Coetzee 1988:22). GSO is daarop gemik om struktuurmerkers, veral die meer subtiele struktuurmerkers, in die teks op te spoor en aan die hand daarvan moontlike aksente en onderliggende (maar tog in die teks aanwesige) gedagtelyne van die skrywer aan te toon (Coetzee 1988:24-25). As sodanig maak dit gebruik van sintaktiese en semantiese struktuurmerkers (Coetzee 1988:27), maar lê veral klem op stilistiese merkers van die gedagte-opbou. Coetzee (1988:2730) doen dan die volgende vyf stappe vir GSO aan die hand:

Stap 1: Herskryf die teks só dat maksimaal een werkwoordstuk per reël voorkom.

Stap 2: Identifiseer voor-die-hand-liggende en meer formele struktuur-merkers.

Stap 3: Identifiseer meer versluierde en/of meer implisiete struktuur-merkers of -patrone.

Stap 4: Sintese: Visuele geheelbeeld van die teks en ontdekte struk-tuurmerkers.

Stap 5: Sintese: Formulering van resultate deur hulle onder woorde te bring.

Toegepas op die teks van die Filippensebrief, bied GSO waardevolle inligting ter ondersteuning van reeds bestaande ontledings van die briefstruktuur.

\section{INDELING VAN DIE BRIEFSTRUKTUUR}

In weerwil van Luter \& Vee (1995:91) se versugting blyk dit dat onlangse resultate van ontledings van die briefstruktuur, selfs vanuit verskillende gesigshoeke, darem nie te ver van 'n konsensus oor die samestelling van die brief eindig nie. Veral die volgende verdien die aandag.

Vanuit 'n epistolografiese ontleding beskryf Russell (1982) die struktuur van Filippense soos volg:
1:1-2 Briefaanhef
1:3-11 Dankseggingsgedeelte
1:12-2:30 Briefliggaam
3:1-4:8 Paranetiese gedeelte
4:10-20 Afloop van die briefliggaam
4:21-23 Briefslot

Russell vind blyke van die eenheid van die brief in die feit dat die dankseggings-gedeelte (1:3-11) woorde bevat wat later in die brief tot temas uitgebou word: 


\section{Die eenheid van die Filippensebrief}

- die $\delta \in \sigma \mu$ ốs van 1:7 word in die briefliggaam uitgebou tot die tema van lyding (1:12-30: Paulus se gevangenskap; en 3:2-3,18-19: stryd teen opponente);

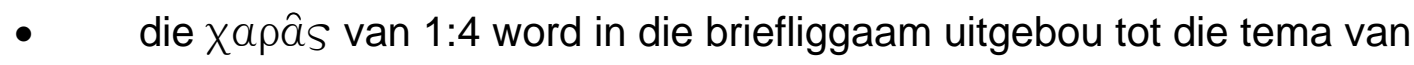
blydskap (1:18,25, ens);

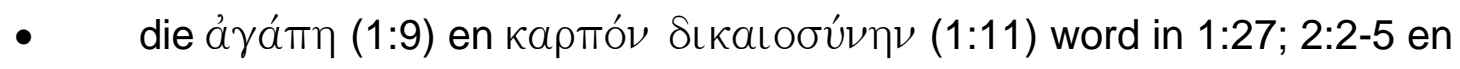
3:2-21 uitgebou tot die tema van die regte geesteseienskappe.

So kom Russell (1982:306) tot die gevolgtrekking dat 1:3-11 as 't ware die inhoudsopgawe van die hele brief is.

Watson (1988) se retoriese analise van die brief (die aanhef en briefslot uitgesluit) sien soos volg daar uit:

$\begin{array}{ll}\text { 1:3-26 } & \text { Exordium } \\ \text { 1:27-30 } & \text { Narratio } \\ \text { 2:1-3:21 } & \text { Probatio } \\ \text { 4:1-20 } & \text { Peroratio. }\end{array}$

Volgens Watson (1988:65-67) bevat die narratio (1:27-30) die topoi wat as onderwerpe in die probatio (2:1-3:21) ontwikkel word, soos volg:

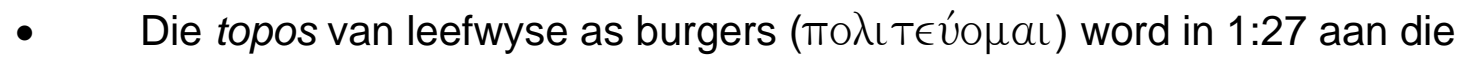

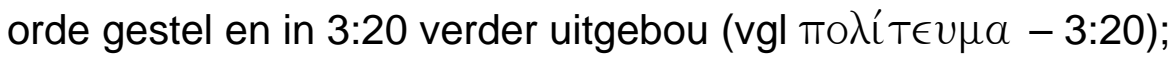

- $\quad$ Die topos van "gemeenskaplike Christelike lyding" word in 1:28-30

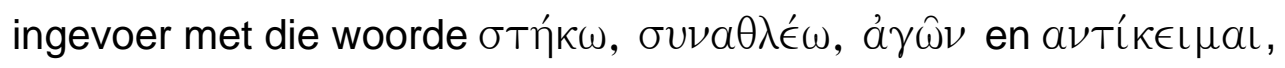
en verder uitgebou in 3:10 en 4:5-7, 14.

Dit blyk dus dat Watson (1988:66) 1:27-30 beskou as die retoriese opgawe ("proposition") van argumente wat later in die briefbetoog uitgebou word. Daarmee identifiseer hy in werklikheid ' $n$ ander "inhoudsopgawe" as Russell se 1:3-11. Tog sluit Watson (1988:64) tot ' $n$ mate by Russell aan, aangesien volgens hom "the prayer of vv. 9-11 anticipates the major proposition of the rhetoric given in 1:27-30."

Swift (1984) maak die volgende tematiese indeling van die briefliggaam:

1:3-11 Proloog (waarin die sentrale tema van die brief aangekondig word: die Filippense se deelname aan die Evangelieverkondiging - vers 5)

1:12-26 Biografiese proloog: Uitbouing van die tema 
1:27-4:9 Die briefliggaam: Verbesondering van die tema
$1: 27-30$
Wandel waardig aan die evangelie
2:1-4:1
Wandel in eenheid en standvastigheid
4:2-9
Wandel in eenheid en standvastigheid
4:10-20 Epiloog: Praktiese bewys van die tema

Swift se tematiese ontleding toon veral twee belangrike sake aan:

- $\quad$ Die feit dat die brief omsluit word deur 'n proloog en 'n epiloog wat beide dank betuig vir die Filippense se deelname aan die verkondiging van die evangelie;

- $\quad$ Die feit dat die briefliggaam opgebou is uit 'n inleidende tema-sin (1:27), gevolg deur drie opeenvolgende besprekings van die tema.

Luter \& Lee (1995) se chiastiese uiteensetting van Filippense, stel 2:17-3:1 (die voorbeeld van Timoteus en Epafroditus tydens Paulus se afwesigheid) as die sentrale wentelpunt van die brief (Luter \& Lee 1995:94):

A. (1:3-11) Proloog: Tema van deelgenootskap ingevoer

B. (1:12-26) Troos/voorbeeld: Paulus se positiewe ingesteldheid t.s.v. gevangenskap

C. (1:27-2:4) Opdrag: Staan eendragtig vas!

D. (2:5-16) Voorbeeld/aksie: Christus se voorbeeld van nederigheid

E. (2:17-3:1) Middelpunt: Tim. en Epafr.as modelle van deelgenootskap

D'. (3:1-21) Voorbeeld/aksie: Paulus se voorbeeld van nederigheid

C'. (4:1-5) Opdrag: Staan vas in blydskap

B'. Troos/voorbeeld: Soek vrede van God; soos Paulus geleer het.

A. (4:10-20) Epiloog: Dankbaarheid vir deelgenootskap wat betoon is.

Luter \& Lee (1995:98) toon aan dat, hoewel die betekenis van 2:17-3:1 in die verlede meestal ongemerk verbygegaan het, daar al meer erkenning is van die belangrike plek wat hierdie verse in die briefliggaam inneem. Hulle spreek die vermoede uit dat Paulus met opset hierdie verse in 'n opvallende plek geplaas het om daarmee aan die kerk in Filippi direkte voorbeelde te gee van hoe hulle moet lewe (Luter \& Lee1995:98).

Black (1995) se diskoersanalise van die brief kan soos volg opgesom word ${ }^{3}$ :

\footnotetext{
${ }^{3}$ Black se uiteensetting van die struktuur korrespondeer naastenby met Kümmel (1972:226227) se samevatting van die inhoud, asook dié van Guthrie (1990:561-563) en Thielman (1995:29).
} 


\section{Die eenheid van die Filippensebrief}

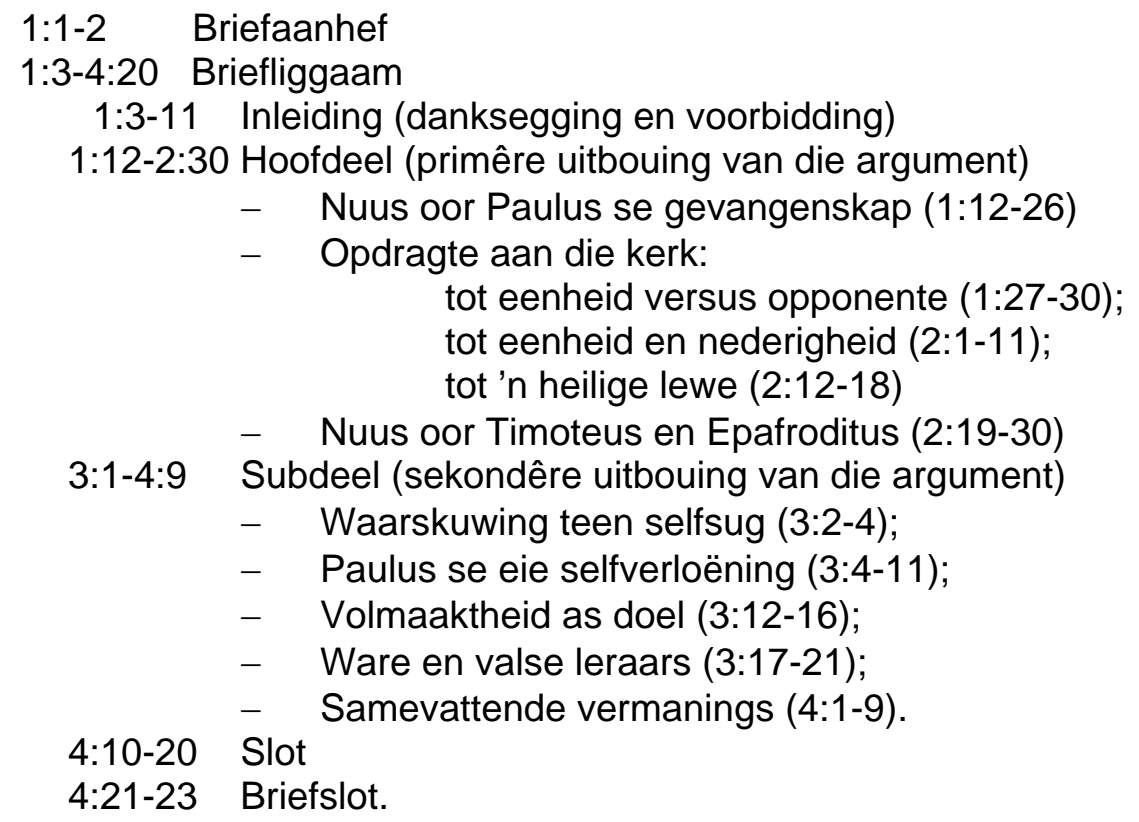

Black (1995:46-49) plaas die briefstruktuur ook binne 'n retoriese raamwerk. In die proses wys hy die volgende verskynsels in die brief-opbou uit wat vir hierdie studie van belang is:

- $\quad$ Die hoofdeel van die brief (1:12-2:30) is in 'n soort chiastiese vorm saamgestel met 1:27-2:18 as die middelpunt van die chiasme, wat as die kern van die brief ${ }^{4}$ bestempel kan word (Black 1995:44).

- $\quad$ Binne hierdie hoofdeel word 1:27-30 saamgesnoer by wyse van

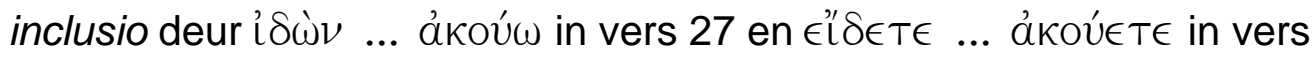
30 (Black 1995:31).

- $\quad$ In 1:27 word die tema van die hele gedeelte vanaf 1:27 tot 2:18 aangekondig: Laat julle gedrag waardig aan die evangelie wees (Black 1995:33).

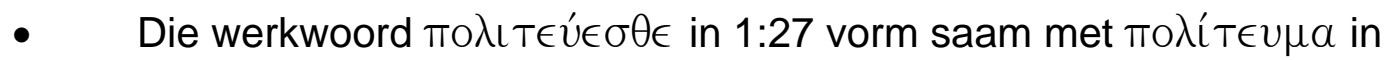
3:20 ' $n$ inclusio wat as 't ware die hele briefliggaam oorspan (Balck 1995:34).

- In 1:27-30 wys Paulus dat hy in sy brief nie net oor dankbaarheid vir hulle ondersteuning (1:3-11) of oor nuus aangaande sy eie omstandighede (1:12-26) gaan nie, maar dat hy deur sy brief 'n bepaalde ingesteldheid en optrede by sy lesers wil bereik (Balck 1995:34).

- $\quad$ Die sinsnede

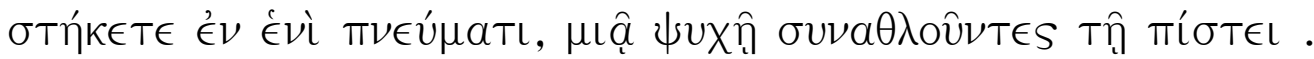

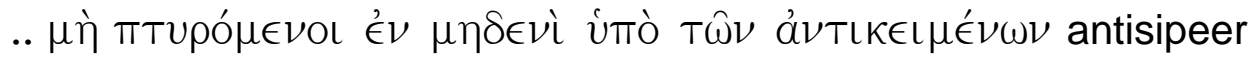
moontlik die waarsku-wings teen wettiese predikers in hoofstuk 3 (1995:35). In 3:1-4:9 word die oproep van 1:27-30, naamlik eendragtige

\footnotetext{
${ }^{4}$ Black (1995:44) se eie woorde: "which we may term the heart of the epistle."
} 
optrede teen opponente, uitgebou ten opsigte van die bedreiging van die Judaïste (Black 1995:41).

Dit blyk dus dat Black se analise 1:27-30 as die sentrum van die briefliggaam uitwys.

By wyse van samevatting blyk dit dat die verskillende ontledings van die teks die volgende indeling van die brief moontlik maak:

\begin{tabular}{|c|c|}
\hline Briefaa & anhef 5 \\
\hline $1: 3-11$ & oop tot die briefliggaam (danksegging en voorbidding) \\
\hline $1: 12-26$ & Inleiding tot die briefliggaam ${ }^{7}$ \\
\hline $1: 27-3: 21$ & Die briefliggaam ${ }^{8}$ \\
\hline $1: 27-30$ & Kern van die briefliggaam ${ }^{9}$ \\
\hline $2: 1-2$ & Aansporing tot eensgesindheid ${ }^{10}$ \\
\hline $2: 3-11$ & Lewenswandel van selfverloëning soos Christus ${ }^{11}$ \\
\hline 2:12-18 & Aansporing tot heilige lewenswandel ${ }^{12}$ \\
\hline $2: 19-30$ & $\begin{array}{l}\text { Mededelings oor Timoteus en Epafroditus tydens sy } \\
\text { afwesigheid }{ }^{13}\end{array}$ \\
\hline 3:1-21 & Waarskuwings teen dwaalleer en dwaalleraars ${ }^{14}$ \\
\hline $4: 1-9$ & Samevattende vermanings ${ }^{15}$ \\
\hline 4:10-20 Afloop & p van die briefliggaam ${ }^{16}$ \\
\hline 4:21-23 Briefs & \\
\hline
\end{tabular}

\footnotetext{
${ }^{5} \mathrm{Vgl} \mathrm{Russell} \mathrm{(1982)} \mathrm{en} \mathrm{Black} \mathrm{(1995).} \mathrm{Oor} \mathrm{die} \mathrm{briefaanhef} \mathrm{en} \mathrm{-slot} \mathrm{is} \mathrm{die} \mathrm{skrywers} \mathrm{almal}$ eenstemmig.

${ }^{6}$ Vgl Watson (1988), Swift (1984), Luter \& Lee (1995) en Black (1995)..

${ }^{7}$ Vgl Swift (1984), Luter \& Lee (1995) en Black (1995).

${ }^{8} \mathrm{Vgl} \mathrm{Watson}(1988)$.

${ }^{9}$ Vgl Watson (1988) en Black (1995) en gedeeltelik Swift (1984).

${ }^{10}$ Vgl Black (1995). Die belang van die "eenheid"-tema word deur elke ander skrywer aangetoon.

${ }^{11}$ Vgl Luter \& Lee (1995) en Black (1995).

${ }^{12}$ Vgl Black (1995).

${ }^{13}$ Vgl Luter \& Lee (1995) en Black (1995).

${ }^{14} \mathrm{Vgl} \mathrm{Vgl} \mathrm{Black}$ (1995) en gedeeltelik ook Watson (1988).

${ }^{15}$ Vgl Black (1995) en gedeeltelik ook Watson (1988) en Swift (1984).

${ }^{16}$ Vgl Russell (1982), Swift (1984), Luter \& Lee (1995) en Black (1995)
} 


\section{Die eenheid van die Filippensebrief}

Uitgaande van bogenoemde indeling van die Filippensebrief is onderstaande gedagtestruktuurontleding daarop gemik om die gedagte-verband tussen 1:27-30 as kern van die brief en die hoofdeel van die brief (2:1-3:21) aan te toon. Met die oog op hierdie doel word in die ontleding gefokus op die gedagtestruktuur van 1:27-30 en vanuit die GSO van hierdie kernverse verbande aangetoon met die temas wat in die res van die hoofdeel deur verskillende analises reeds aangetoon is.

\section{GEDAGTESTRUKTUUR VAN 1:27-30}

In ooreenstemming met die stappe wat Coetzee (1988) vir 'n GSO voorstel, word die volgende ontleding van die gedagtes van Filippense 1:27-30 gedoen:

\subsection{Herskryf die teks}

Die eerste stap is om die Griekse teks so te herskryf dat die woordorde nie versteur word nie en daar nie meer as een werkwoordstuk per reël voorkom nie:

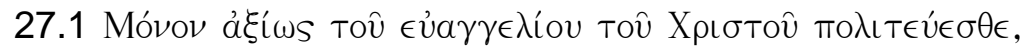

27.2 iva $\epsilon^{2} \mathrm{l} T \in \hat{\epsilon} \lambda \theta \dot{\omega} \nu$

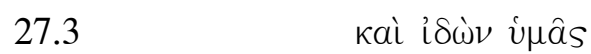

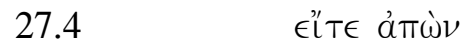

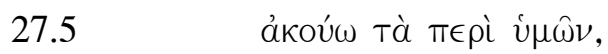

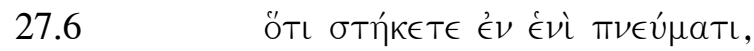

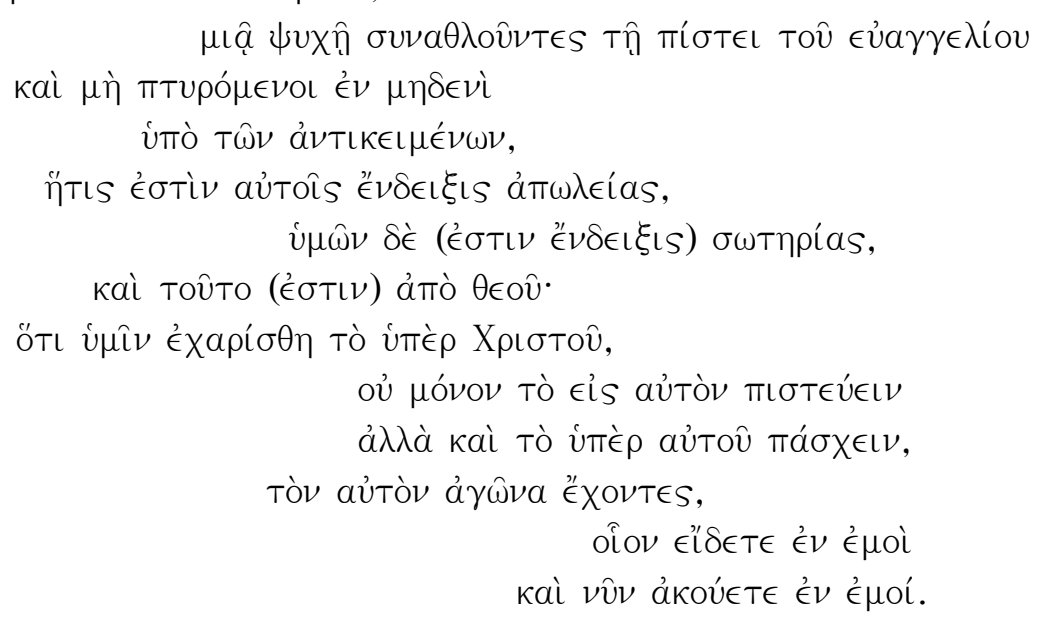

Die herskrywing van die teks is, volgens aanduiding deur Coetzee (1988:27) so gedoen dat elliptiese werkwoorde in hakies voorsien is. Ook deelwoorde en infinitiewe is op afsonderlike reëls geskrywe. Die reëls is verder so geplaas dat ooreenstemmende komponente waar moontlik onder mekaar staan, ten einde identifisering van patrone te vergemaklik. 


\subsection{Sintaktiese verbande}

Die sintaktiese ontleding van 1:27-30 word, met die oog op GSO, beperk tot die aanduiding van hoof- en bysinne, oftewel grammatiese ekwivalente daarvan. Dit blyk dan dat 1:27-30 een lang periode vorm, bestaande uit een hoofsin, opgevolg deur 'n doelsin, wat op sy beurt verder uitgebrei word deur 'n reeks kwalifikasies. Hieronder volg dan 'n uiteensetting van die sintaktiese verbande, met verwysing tussen hakies na die herskrewe tekskomponente in 4.1 hierbo.

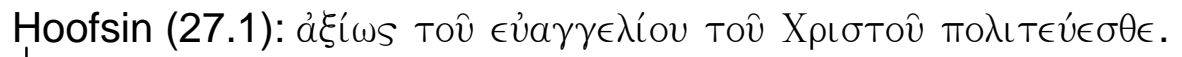

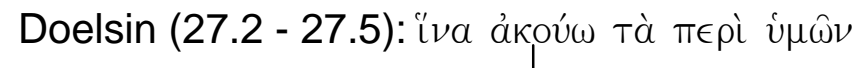

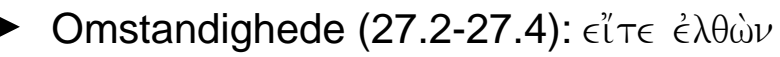

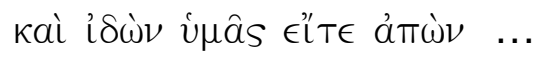

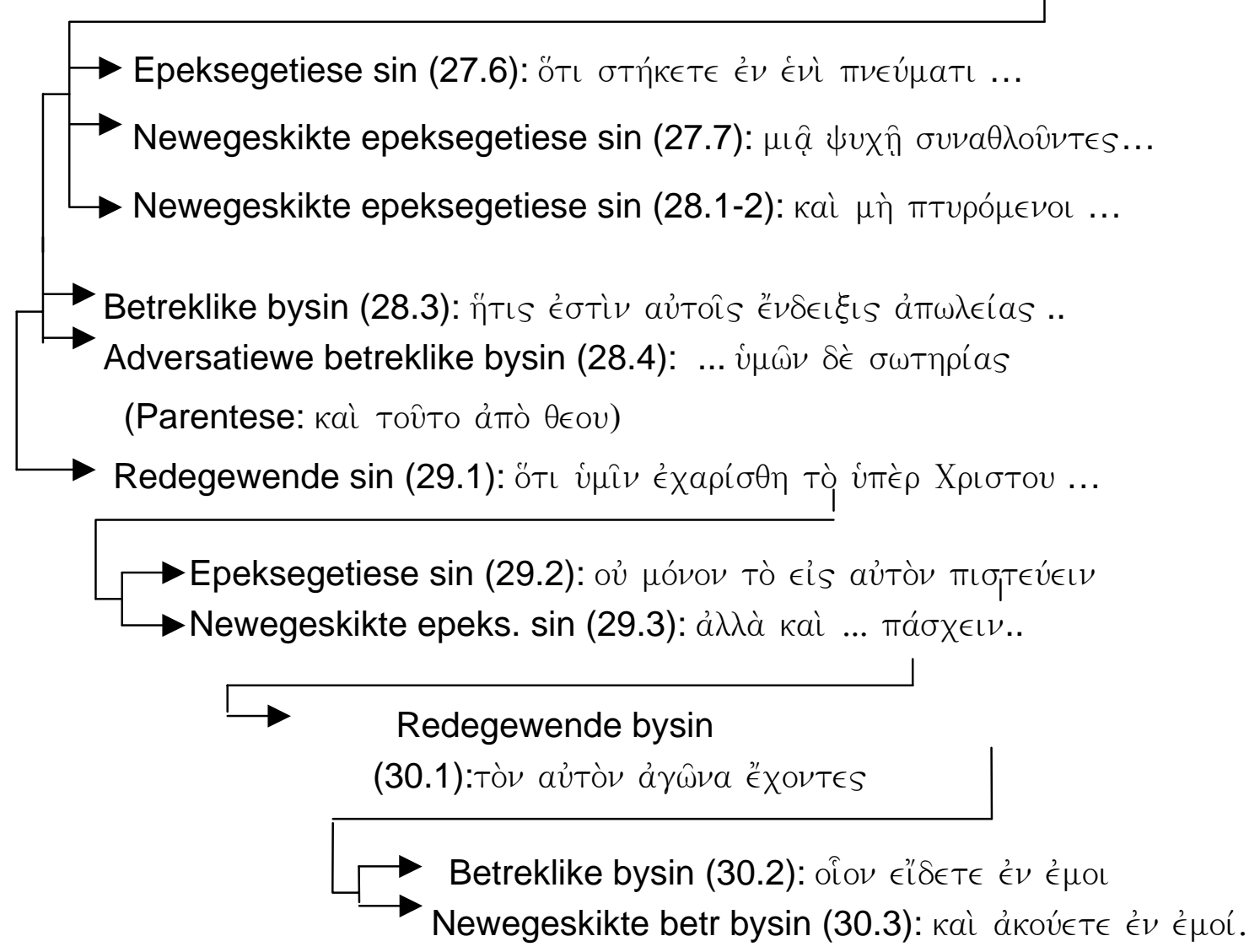




\section{Die eenheid van die Filippensebrief}

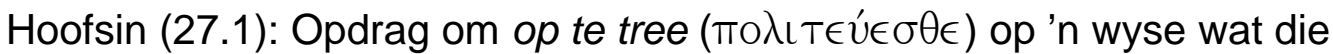
evangelie van Christus waardig is.

Doelsin (27.2 - 27.5): dat ek die dinge aangaande julle kan verneem

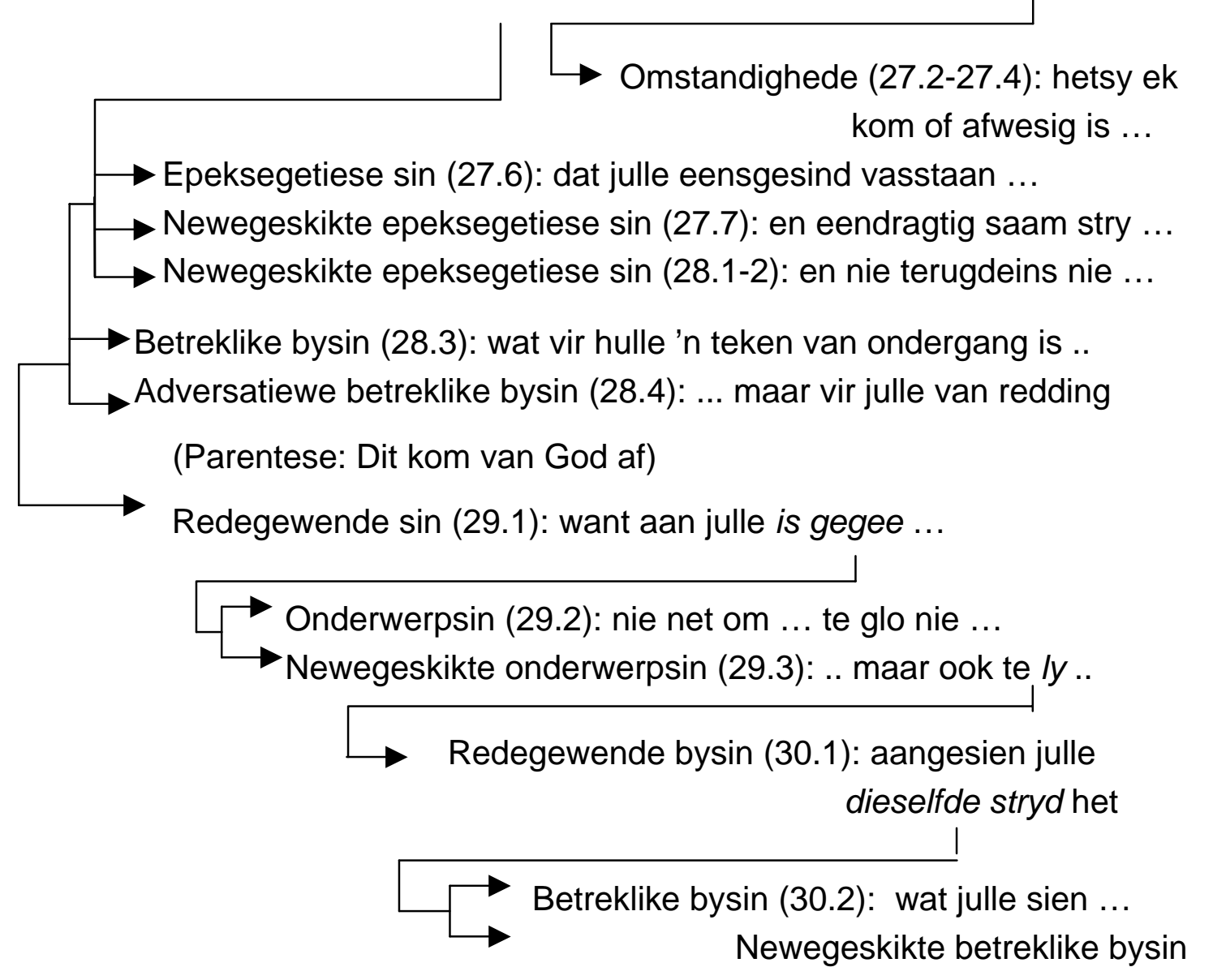

(30.3): en hoor.

Die belangrikste enkele punt wat uit die sintaktiese ontleding van 1:27-30 na vore kom, is dat die hoofgedagte waarskynlik in 27.1 geleë is, aangesien dit die gramma-tikale hoofsin van die periode vorm.

\subsection{Meer implisiete struktuurmerkers}

Coetzee stel nie duidelik waar hy die grens tussen meer eksplisiete en meer implisiete struktuurmerkers trek nie. In ieder geval, waar ook al die grens lê, word beide ondervang in die proses van stappe 2 en 3.

In die volgende uiteensetting word vanaf die herskrewe teks enkele moontlike struktuurmerkers visueel aangetoon en bespreek. Dit beteken dat Coetzee se stappe 3 en 4 in een visuele geheelbeeld aangebied word ( $L$ W: ten einde die "meer implisiete" merkers "meer eksplisiet" voor te stel, is die herskrewe teks soms verder onderverdeel): 


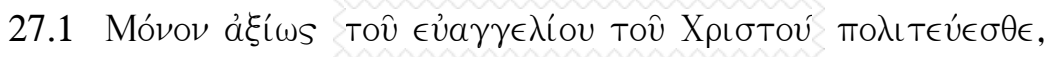

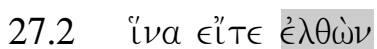

27.3 кaì i̇ंùv inâs

27.4

27.5

27.6 Tà $\pi \epsilon \rho \grave{~} u \mu \omega ̂ \nu$,

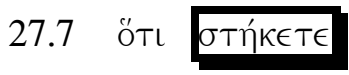

27.8

27.9

27.10

27.11

28.1

28.2

28.3

28.4

28.5

28.6

29.1

29.2

29.3

30.1

30.2

30.3

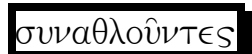

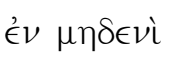

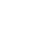

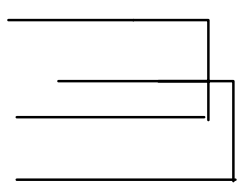

a

a

b
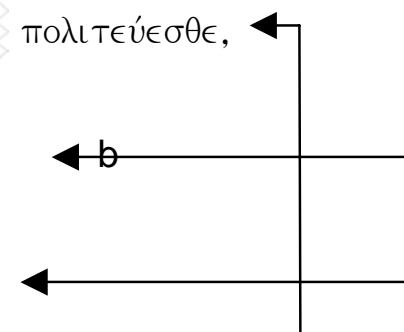

Év Évì $\pi \nu \in \dot{v} \mu a T \mathrm{~L}$, $\mu \iota \hat{\alpha} \psi v \times \hat{n}$

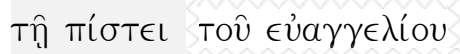
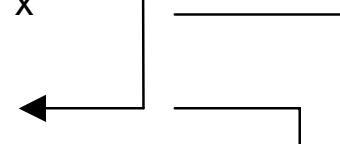

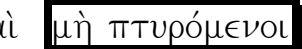

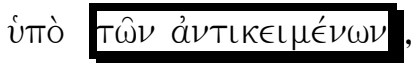

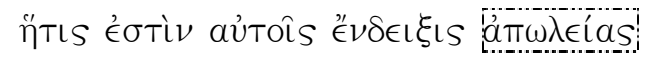

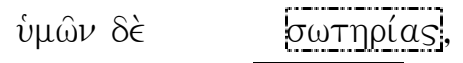

$$
\begin{aligned}
& \text { каї тоиิто ä́ò } \theta \in \text { Ev. }
\end{aligned}
$$

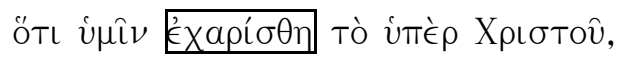

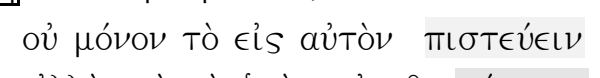

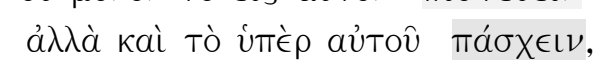

antitese

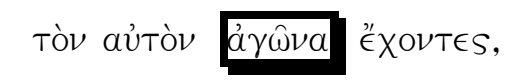

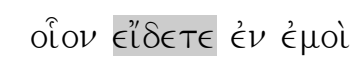

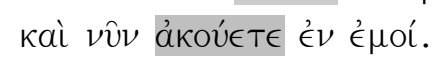

\subsubsection{Herhaling van semanties verwante begrippe}

Een van die opvallendste struktuurmerkers is herhaling. In verse 27-30 is daar, soos in bostaande uiteensetting aangetoon word, 'n opvallende herhaling van

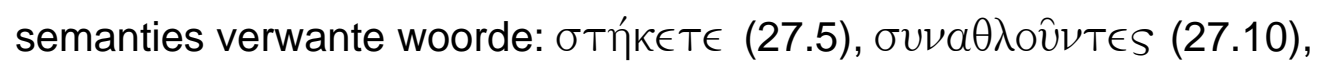

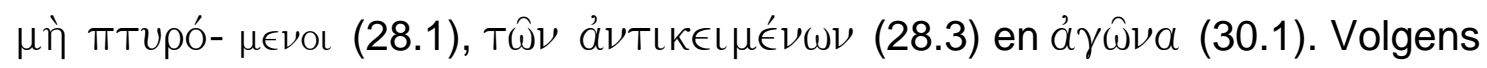
Bouwman (1965:45) en Schenk (1984:167) is al hierdie woorde se gebruiksveld van militêre oorsprong. Geoffrion (vgl Pretorius, 1995:286) plaas die woorde binne 'n politieke/militêre betekenisveld, terwyl Houlden (1977:66) en Moule (1977:58-60) van mening is dat die woorde eerder met sportkompetisies (spele) verband hou. Caird (1976:115) en Watson (1988:67) neem 'n middelstandpunt in: die woorde is "metaphoric terms from battle and athletic contests" (Watson, 1988:67). Indien die sosio-historiese konteks van die eerste lesers in berekening 
gebring word, lyk dit of die siening van Bouwman en Schenk nagevolg behoort te word. Bouwman (1965:46) wys daarop dat die gemeente in Filippi grootliks uit oorlogsveterane bestaan het en dat Paulus hulle daarom baie effektief met woorde vanuit hulle eie (militêre) verwysingsraamwerk bedien (vgl ook Coetzee 1975:92).

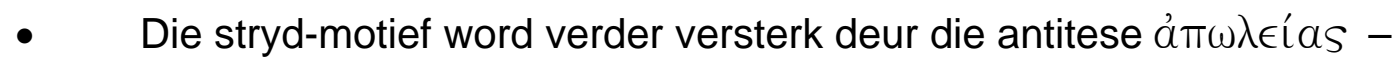

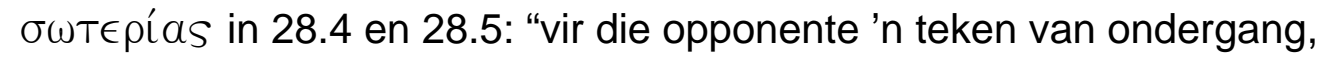
vir julle 'n teken van redding".

- $\quad$ Dat die oorlogsterme in hierdie verse metafories gebruik word met verwysing na 'n geloofstryd, word bevestig deur die verbinding van

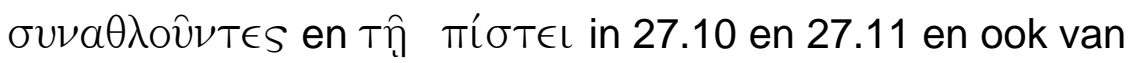
$\pi \iota \sigma T \in \dot{\epsilon} \iota \nu$ en $\pi \alpha ́ \sigma \chi \in \iota \nu$ in 29.2 en 29.3. Veral deur laasgenoemde verbinding toon die skrywer aan dat die gawe van geloof óók lyding ter wille van Christus insluit, waarby die lyding van stryd teen geloofsopponente inbegrepe is (vgl Schenk 1984:170).

- Die semanties verwante frases kaì тоûto átò̀ $\theta \in$ ou (28.6) en ú nie net geloof nie maar ook die geloofstryd

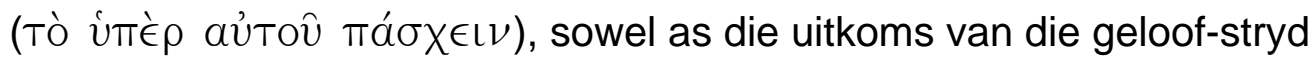

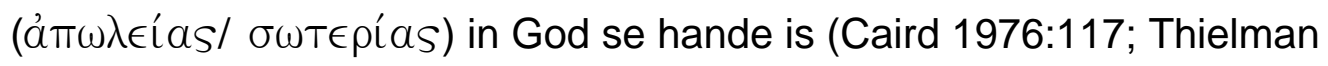
1995:94).

Dit blyk dus dat die gedagte van geloofstryd 'n belangrike plek in die perikoop beklee.

\subsubsection{Inclusio deur etimologies verwante woorde (verse 27-30)}

Soos in bostaande uiteensetting aangedui, bind die herhaling van

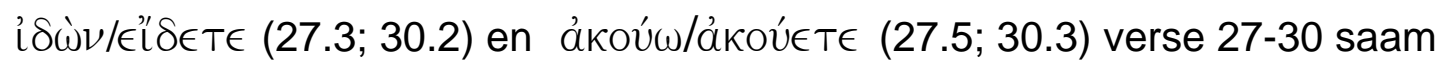
by wyse van 'n ringkomposisie oftewel inclusio (vgl Bouwman 1965:44; Black 1995:34).

\subsubsection{Inclusio deur herhaling (vers 27)}

Binne die geheel van verse 27-30 vorm vers 27 'n kleiner geheel, ook by wyse van inclusio (ringkomposisie) saamgebind deur

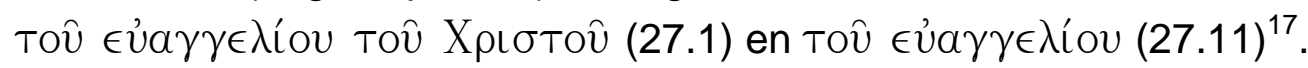

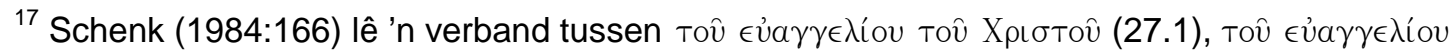

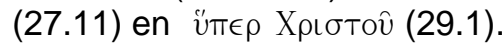




\subsubsection{Parallelisme en chiasme (vers 27)}

Die inclusio omsluit twee herhalingspatrone: 'n parallellisme (a-b-a-b) in 27.2 tot 27.5 en 'n chiasme $(x-y-y-x)$ in 27.7 tot 27.10.

- $\quad$ In die chiasme word op treffende wyse aangedui dat die lesers die stryd moet voer in volkome eensgesindheid

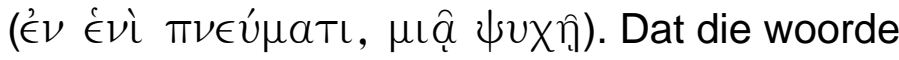
Év Évi $\pi v \in \hat{u} \mu a T \iota, \mu \iota \hat{\alpha} \psi v \chi\rceil \eta$ die belangrike tema van "eenheid" in die brief invoer, word deur verskeie kommentatore aangetoon ( $\mathrm{vgl}$ Bouwman 1965:46; Caird 1976:114; Moule 1977:57; Aspan, soos aangedui deur Pretorius 1995:280-281). Binne die raamwerk van verse 27-30 beklee die gedagte van eensgesindheid dus ' $n$ belangrike plek.

- Die parallellisme in 27.2 tot 27.5 vestig die aandag op die verband tussen die apostel se "sien" en "hoor" en sy toekomstige bewegings: of hy die gemeente persoonlik gaan besoek ( $\left.\hat{\epsilon}^{\prime} \lambda \theta \dot{\omega} \nu\right)$ of nie $(\hat{\alpha} \pi \dot{\omega} \nu)$ - die sogenaamde apostoliese parousie (vgl Russell 1982:303). Die frase

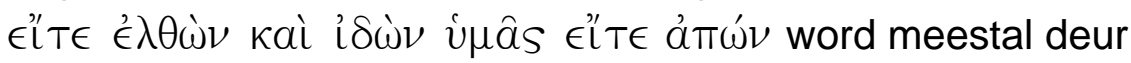
kommentatore oor die hoof gesien, miskien omdat dit sintakties die plek van 'n (blote) parentese (Schenk 1984:165) inneem. Hoewel 'n parentese, kan die woorde tog nie geïgnoreer word nie. Inteendeel, die feit dat die apostel hierdie woorde by wyse van die parallellie in 'n opvallende posisie geplaas het, dui daarop dat dit spesiale aandag verdien. Dit blyk verder dat die apostoliese teenwoordigheid aan die "sien-hoor"-inclusio verbind is: by wyse van parallellie in 27.2 tot 27.5

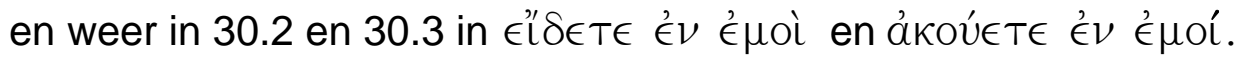
Daarom kan die apostoliese teenwoordigheid as 'n belangrike komponent van die perikoop beskou word.

\subsection{Formulering van resultate}

By wyse van sintese kan die gedagtestruktuur van 1:27-30 dan soos volg weergegee word:

Basiese opdrag: Leef so dat julle optrede die evangelie van Christus waardig is.

\section{Waarom moet julle so leef?}

Sodat ek (goeie getuienis) aangaande julle kan verneem

Op watter manier sal ek die getuienis verneem?

Wel, óf ek kom julle self besoek en kyk, óf ek sal in my afwesigheid hoor.

Wat(ter goeie getuienis) verwag ek om aangaande julle te verneem?

1. dat julle in die stryd teen geloofsopponente vasstaan;

2. dat julle die stryd eensgesind en eendragtig voer. 
Met watter sekerheid kan julle in die stryd volhard?

1. dat God aan julle die genade gee om in Christus te glo;

2. dat dit ook genade van God is om vir Christus te ly (te stry);

3. dat ook die uitkoms van stryd deur God bepaal is (ondergang/redding).

Watter voorbeeld van geloofstryd het julle?

Wel, dit is dieselfde stryd as wat julle my hoor en sien voer.

Kort saamgevat blyk dit uit die GSO dat Paulus in verse 27-30 die volgende gedagtes op een of ander wyse in die kalklig stel:

DIE BASIESE OPDRAG AAN DIE LESERS:

'n Lewenswandel waardig aan die evangelie van Christus.

DIE APOSTEL SE TEENWOORDIGHEID BY DIE LESERS:

Die verwagting om die gemeente te sien of nie.

DIE EENSGESINDHEID VAN SY LESERS:

Hulle moet een van siel en gees wees.

DIE GELOOFSTRYD VAN DIE LESERS:

Dat hulle teen hulle opponente moet vasstaan.

- die troos vir die stryd: in God se hande

- die voorbeeld vir die stryd: Paulus se eie stryd.

\section{DIE PLEK VAN 1:27-30 BINNE DIE BRIEFLIGGAAM}

Wanneer die sintese van die gedagtestruktuur van 1:27-30 met die struktuur van die hoofliggaam van die brief vergelyk word, is die ooreenkoms opvallend:

$1: 27-30$

- 'n Lewenswandel waardig die evangelie van Christus

- Paulus se teenwoordigheid of afwesigheid

- Die eensgesindheid van sy lesers

- Die geloofstryd van sy lesers
$2: 1-3: 21$

Aansporing tot ' $n$ heilige lewenswandel, nederig soos Christus (2:3-

18)

Timoteus en Epafroditus teenwoordig tydens Paulus se afwesigheid (2:19-30) Aansporing tot eensgesindheid (2:12)

Waarskuwing om te stry teen dwaalleer en dwaalleraars (3:1-21). 
Waar Russell (1982:306) 1:3-11 as die "inhoudsopgawe" van die hele brief beskou, dui 'n GSO daarop dat 1:27-30 as "ínhoudsopgawe" van die hoofliggaam van die brief beskou kan word. Hierdie struktuur van die hoofliggaam kan dan as 'n "driehoek"-patroon voorgestel word, waarin die kerngedagte(s) aan die begin vermeld word (in hierdie geval die "inhoudsopgawe") en verdere uitbouing daarvan die breër-wordende deel van die driehoek uitmaak:

$1: 27$

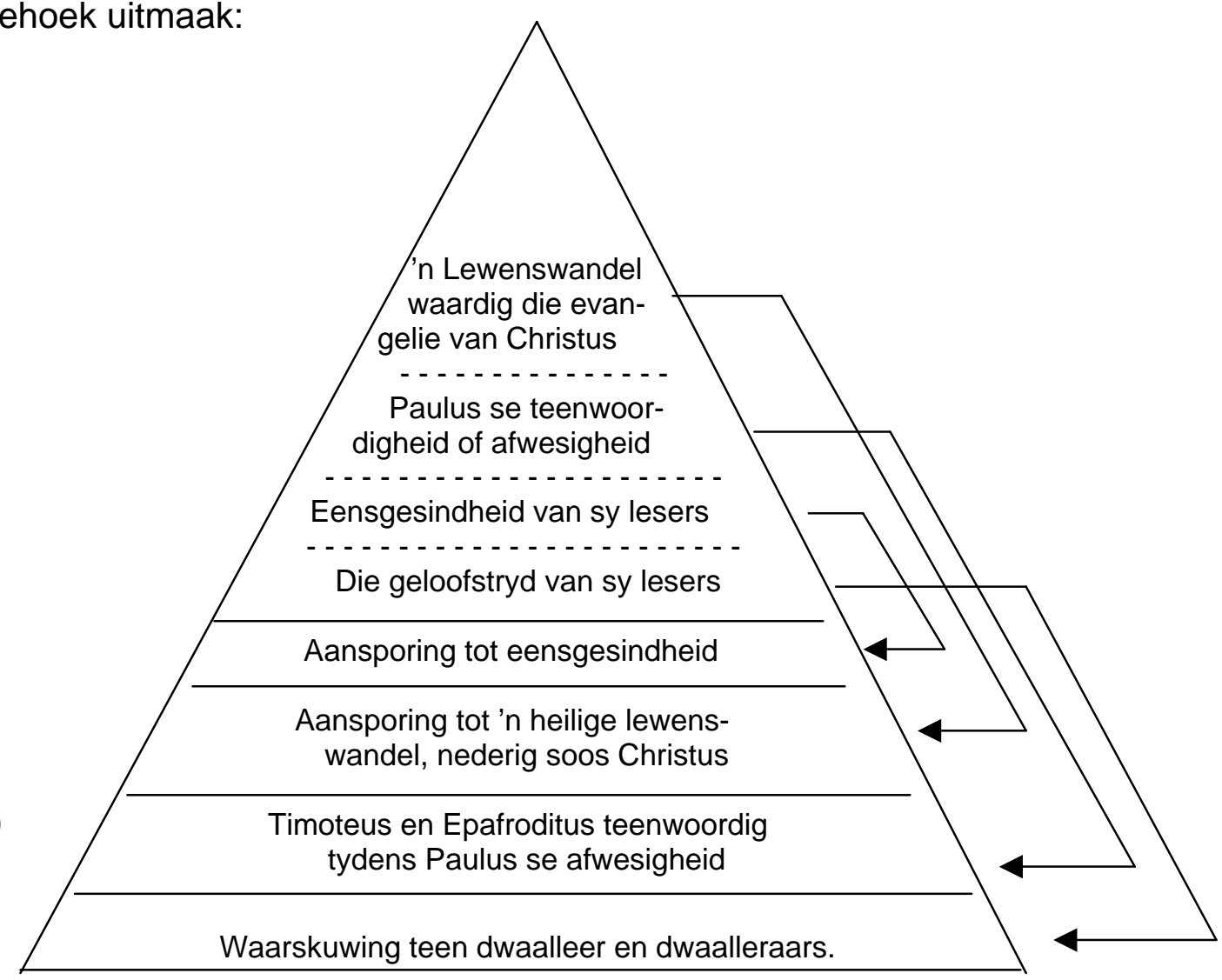

Ook in die samevattende vermanings (4:1-9) kom die gedagtes van die "inhoudsopgawe" van 1:27-30 (samevattend) weer na vore, soos volg (vgl Black 1995:41-42):

\section{$1: 27-30$}

- 'n Lewenswandel waardig die evangelie van Christus

- Paulus se afwesigheid

- Paulus se verlange (4:1)

- Die eensgesindheid van sy lesers

- Stry saam vir die evangelie

- Troos in die geloofstryd

\section{4:1-9}

Bedink alles wat edel is en doen wat julle geleer is (4:8-9)

Paulus se verlange (4:1)

Staan vas in die Here $(4: 1)$

Vermaning tot eensgesindheid (4:2)

Vroue wat saamgestry het in die

Wees oor niks besorg nie, bid en julle sal

God se vrede ontvang (4:6-9). 


\section{Die eenheid van die Filippensebrief}

So blyk dit dat 1:27-30 nie net die "inhoudsopgawe" vir 2:1-3:21 bevat en so die hoofliggaam van die brief tot 'n hegte eenheid verbind nie, maar dat dit ook, by wyse van inclusio of ringkomposisie saam met 4:1-9, die hoofliggaam van die brief omsluit en tot 'n eenheid saambind.

\section{GEVOLGTREKKING}

Indien bostaande GSO van 1:27-30 korrek is, dan lyk dit of die gedagtes daarvan in wese saamgestel is uit die temas wat in die hoofliggaam van die brief voorkom. As sodanig bied dit dan 'n "inhoudsopgawe" of "vooraf-agenda" van die sake wat in die hoofliggaam van die brief deur Paulus bespreek word. Hiermee word, saam met reeds bestaande struktuurontledings van die brief, verdere getuienis gebied vir die inherente eenheid van die briefliggaam van Filippense. As sodanig bied dit ook verdere getuienis teen die teorie van 'n gekompileerde Filippensebrief. Teenoor Schenk (en ander ondersteuners van die kompilasie-teorie) se aanname dat 3:2-4:3 oorspronklik 'n afsonderlike brief was (Fragment C, vgl Schenk 1984:250), dui bostaande ontleding van die brief se gedagtestruktuur daarop dat 1:27-3:21 weliswaar uit die staanspoor as 'n eenheid geskryf, en bes moontlik ook so deur die skrywer beplan is.

\section{Literatuurverwysings}

Black, D A 1995. The discourse structure of Philippians: A study in textlinguistics. Novum Testamentum 37(1), 16-49.

Bouwman, G 1965. De brief van Paulus aan de Filippiërs. Roermond: J J Romen.

Caird, G B 1976. Paul's letters from prison. London: Oxford University Press.

Coetzee, J C 1975. Die Blye Boodskap: 'n Gids deur die Boeke van die Nuwe Testament. I: Die briewe van Paulus. Potchefstroom: Pro Rege.

Coetzee, J C 1988. Gedagtestruktuurontleding en die eksegese van die Heilige Skrifte, in Coetzee, J C (red), Koninkryk, Gees en Woord, 19-37. Pretoria: NG Kerkboekhandel.

Combrink, H J B 1989. Response to W Schenk, Die Philipperbriefe des Paulus. Semeia 48, 135-146.

Guthrie, D 1990. New Testament Introduction. Illinois: InterVarsity Press.

Houlden, J L 1977. Paul's Letters from prison. London: SCM. (SCM Pelican Commentaries.)

Koperski, V 1992. Textlinguistics and the integrity of Philippians: A critique of Wolfgang Schenk's arguments for a compilation hypothesis. Ephemerides Theologiae Lovaniensis 68(4), 331-367.

Koperski, V 1993. The early history of the dissection of Philippians. JTS 44(2), 599603.

Kümmel, W G 1972. Introduction to the New Testament. London: SCM.

Luter, A B \& Lee, M V 1995. Philippians as chiasmus: Key to the structure, unity and theme questions. NTS 41, 89-101.

Moule, H C G 1977. Studies in Philippians. Grand Rapids, MI: Kregel. 
Pretorius, E A C 1989. A key to the literature on Philippians. Neotestamentica 23(1), 125-153.

Pretorius, E A C 1995. New trends in reading Philippians: A literature review. Neotestamentica 29(2), 273-298.

Pretorius, E 1998. Role models for a model church: Typifying Paul's letter to the Philippians. Neotestamentica 32(2), 547-571.

Roberts, J H 1984. Die Gevangenskapsbriewe, in Du Toit, A B (red), Handleiding by die Nuwe Testament V, 114-157. Pretoria: NG Kerkboekhandel.

Russel, R 1982. Pauline letter structure in Philippians. Journal of the Evangelical Theological Society 25, 295-306.

Schenk, W 1984. Die Philipperbriefe des Paulus. Stuttgart: Kohlhammer.

Swift, R C 1984. The theme and structure of Philipians. Bibliotheca Sacra 141, 235254.

Thielman, F 1995. Philippians. Grand Rapids, MI: Zondervan. (The NIV Application Commentary.)

Watson, D F 1988. A rhetorical analysis of Philippians and its implications for the unity question. Novum Testamentum 30(1), 57-88. 